\title{
Intrascrotal lipoblastoma: report of a case and the review of literature
}

\author{
Keigo Yada ${ }^{*}$, Hiroki Ishibashi, Hiroki Mori and Mitsuo Shimada
}

\begin{abstract}
Intrascrotal lipoblastoma is a rare pediatric benign soft tissue neoplasm, and only 11 cases have been reported. The accurate preoperative diagnosis is difficult because of its rarelity and the similarity with the other soft tissue tumors. Among them, accurate preoperative diagnosis had been made in only one case. Thus, almost all of the cases had required inguinal mass excision (and orchidectomy in one case). In this paper, we discuss the accurate preoperative diagnosis of intrascrotal lipoblastoma and subsequent simple tumorectomy via minimal invasive scrotal skin incision, in 1-year-old boy. On physical examination, intrascrotal extra-testicular lobulated mass was palpated on the right scrotum. An ultrasonography revealed the well-circumscribed, iso-echoic, scant blood-flow, and lobulated tumors with each lobules of 1 to $4 \mathrm{~cm}$ in diameter, and the tumor located outside of the tunica vaginalis testis. The serum values of alpha-fetoprotein (AFP) and beta-human chorionic gonadotropin (b-hCG) were within normal limit. The preoperative diagnosis of intrascrotal lipoblastoma was made, and the mass was excised via minimal scrotal incision. The right testicle and epididymis were normal. The lesion consisted of the distinct two lobulated tumors, and microscopic examination confirmed the diagnosis of intrascrotal lipoblastoma. The postoperative course was uneventful without evidence of recurrence. A rare intrascrotal lipoblastoma is seldom made accurate preoperative diagnosis; however, the accurate preoperative suspicion of this tumor leads to the minimal invasive tumorectomy via scrotal skin incision and favorable postoperative recovery without recurrence.
\end{abstract}

Keywords: Intrascrotal lipoblastoma, Scrotal incision, Preoperative diagnosis

\section{Background}

In the first two decades of life, adipose tumors are relatively rare, comprising about $6 \%$ of soft tissue neoplasms. About $60 \%$ of these are simple lipomas or variants, and up to $30 \%$ are lipoblastomas [1]. It is found most commonly in the trunk or upper and lower extremities as a painless nodule or mass [1]. Less common sites of involvement include the head and neck area [2], mediastinum [3], mesentery [4], omentum [5], retroperitoneum [6], and scrotum [7-16]. The accurate preoperative diagnosis is difficult because of its rarelity and the similarity with the other soft tissue tumors [17]. Previously, 11 cases of intrascrotal lipoblastoma have been reported [7-16]. Among them, accurate preoperative diagnosis had been made in only one case [14], and an another case had been underwent orchidectomy due to the preoperative suspicion of paratesticulsr rhabdomyosarcoma [13]. This report describes a case in which

\footnotetext{
* Correspondence: k-yada@tokushima-u.ac.jp

Department of Surgery, The University of Tokushima, 3-18-15 Kuramoto-cho, Tokushima City, Tokushima 770-8503, Japan
}

accurate preoperative diagnosis of this rare tumor $\mathrm{z}$ procedure (e.g., inguinal incision and orchidectomy) and to result in the favorable outcomes.

\section{Case presentation}

A 1-year and 7-month-old boy was taken to his pediatrician after his family members noticed a right swollen scrotum. An intrascrotal tumor was suspected, and he was referred to our pediatric surgery department. On physical examination, a $7-\mathrm{cm}$ lobulated mass was palpated on the right scrotum, apart from the normal bilateral testes (Fig. 1). The rubbery-hard tumor had smooth surface and was mobile, suggesting benign pathology. An ultrasonography revealed the well-circumscribed, hyper-echoic, scant blood-flow, and lobulated tumors with each lobules of 1 to $4 \mathrm{~cm}$ in diameter, and the tumor is located outside of the tunica vaginalis testis. A contrast computed tomography (CT) scan showed the less enhancement of the tumors. All of the tumors revealed the high intensity on magnetic resonance imaging (MRI) T2-weighted image, but T1-weighted image showed 


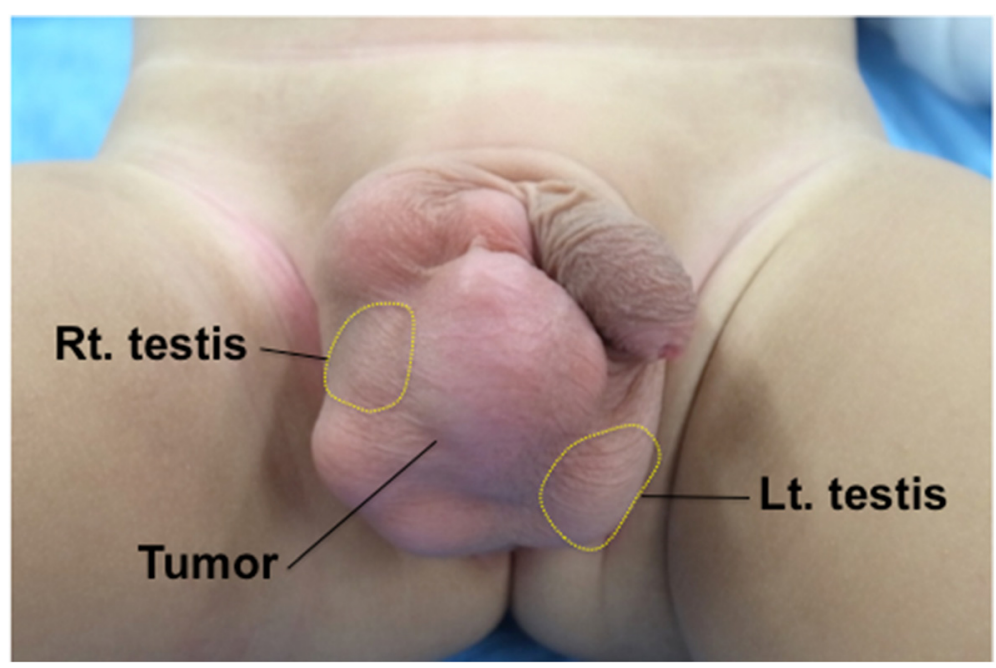

Fig. 1 The preoperative finding of the scrotum. The tumors were apart from the bilateral testes

the mosaic pattern (e.g., T1-low lesions and T1-high lesions were co-existed) (Fig. 2a, b). The serum values of alphafetoprotein (AFP) and beta-human chorionic gonadotropin (b-hcg) were within normal limit. We considered that the most likely preoperative diagnosis is the intrascrotal lipoblastoma, as the previously reported cases $[8,10,11,14,15]$ had the quite similar features (e.g., a young child with wellcircumscribed and lobulated intrascrotal lipoid mass apart from the testes or the epididymis) with our case. The other differential diagnoses were rhabdomyosarcoma, lipoma, and liposarcoma. The mass was excised by scrotal incision (Fig. 3b). The lesion developed out of the cord and was independent of the right testicle and of the processus vaginalis (Fig. 3a, b). The right testicle was normal (Fig. 3a). The lesion consisted of the distinct two lobulated and wellcircumscribed tumors with diameters of $6 \mathrm{~cm} \times 4 \mathrm{~cm} \times$ $3 \mathrm{~cm}$ and $3.5 \mathrm{~cm} \times 2 \mathrm{~cm} \times 2 \mathrm{~cm}$, respectively (Fig. 4).

Microscopically, both tumors were multilobulated tumors of adipose tissue and were surrounded by the capsule composed of loose connective tissue. Lobules were separated by fibrous septa and were composed of mature adipocytes and vacuolated lipoblasts showing varying degrees of differentiation. Both tumors were diagnosed as lipoblastoma (Fig. 5).

The postoperative course was uneventful, and the patient discharged home on postoperative day 1 . The patient has been followed up for 8 months, without evidence of recurrence.

\section{Discussion}

Lipoblastoma, a relatively rare tumor of embryonal fat, is characterized by its benign nature, early presentation (90\%<3 years) [18], male predominance of 3:1 [19], and rapid growth. Although it is found most commonly in the trunk or upper and lower extremities [1], the involvement of the other lesion (e.g., head/neck [2], mediastinum [3], mesentery [4], omentum [5], retroperitoneum, and scrotum (Table 1) [7-16]) has been reported. The differential
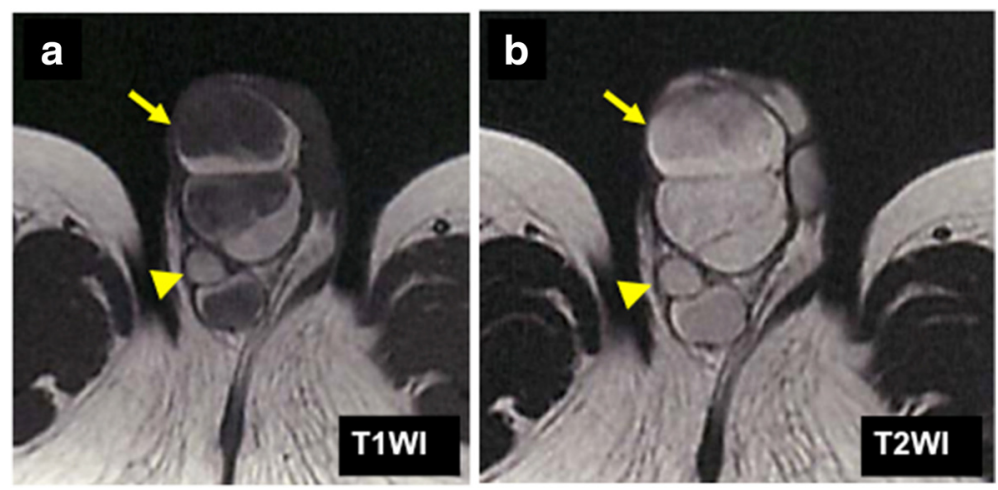

Fig. 2 The MRI findings. a T1-weighted image showed the mosaic pattern (e.g., T1-low lesions and T1-high lesions were co-existed). b All of the tumor revealed the high intensity on T2-weighted image. (Arrow heads indicate right testis.) 

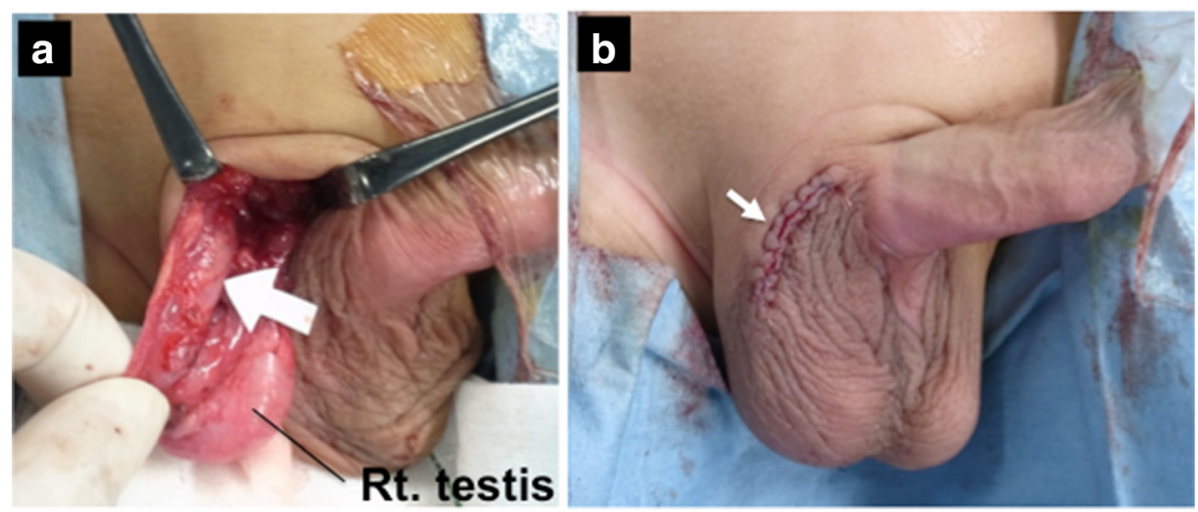

Fig. 3 Operative findings of the scrotum. a The lesion located out of the cord and was independent of the normal right testicle and of the processus vaginalis. (White arrow indicates the tumor location.) b The mass was excised via the minimal scrotal incision

diagnoses of pediatric intrascrotal paratesticular tumor include benign tumors (e.g., lipoma, lipoblastoma, leimomyoma, and hemangioma) and malignant tumors (e.g., rhabdomyosarcoma, liposarcoma, and melanotic neuroectodermal tumor of infancy (MNTI)) [15, 20]. Of these, leiomyoma and MNTI generally originate from the epididymis, and hemangioma has the much vasculature. So at first, we could deny these three tumors. Rhabdomyosarcoma is the most common paratesticular malignancies in pediatric population [21], and it arises from the tunicae of the testis, epididymis, and spermatic cord. But, rhabdomyosarcoma commonly occurs in older children with median age of 7 years old [22] and reveals heterogeneous echogenicity and increased blood flow in ultrasonography (US) [23]. Liposarcoma lacks lobulated shape, and occurrence in pediatric population is extremely rare [20]. Also, lower intensity of T1-weighted MRI image has been noted with lipoblastoma compared with lipoma [24], likely because of increased cellularity. In our case, the intratumoral mosaic pattern (e.g., T1-low lesions and T1-high lesions were co-existed) on T1-weighted image suggested the lipoblastoma, rather than a lipoma. Furthermore, lipoblastoma has the following distinguishable characteristics: I: commonly involves in patients younger than 3 years old, predominantly in male by 3:1 and II: well-circumscribed, lobulated, hypovascular fatty tumor. Thus, we could make accurate preoperative diagnosis of lipoblastoma. Our case is the second case in which accurate preoperative diagnosis of lipoblastoma could be made (Table 1). However, the differential diagnosis of intrascrotal tumor in older patients might be more complicated, because the origin of the testicular or paratesticular might sometimes unclear. The
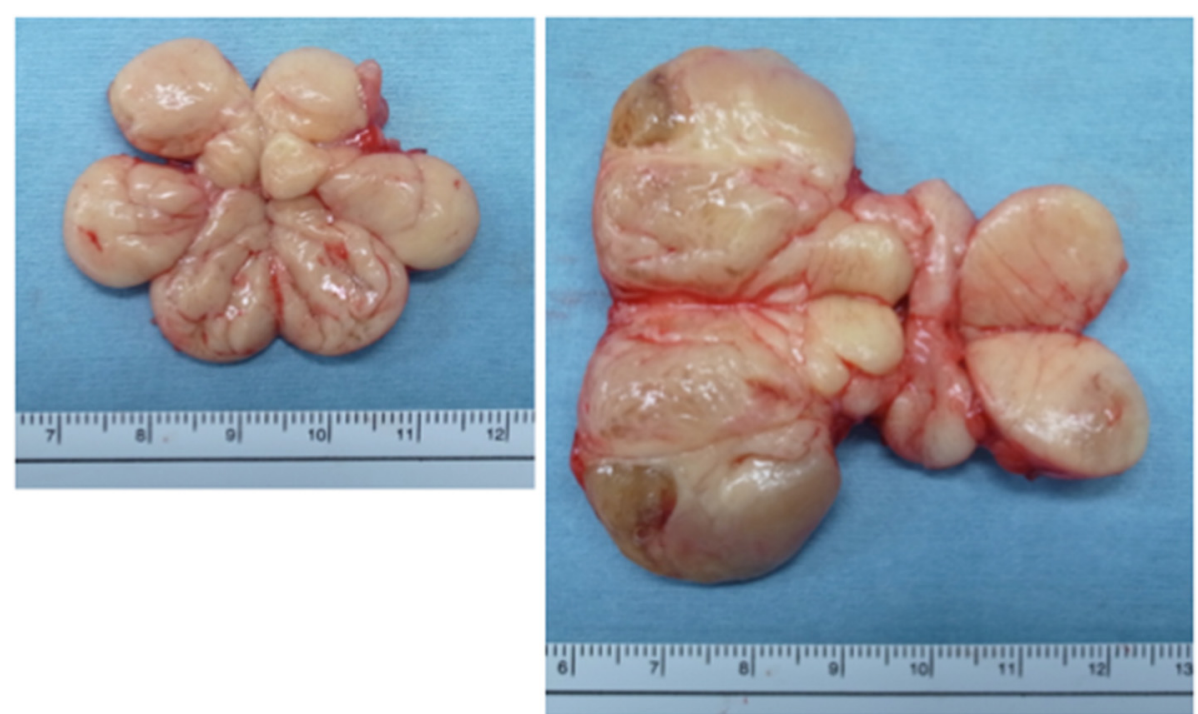

Fig. 4 The cut surface of the specimens. The lesion consisted of the distinct two lobulated and well-circumscribed tumors with diameter of $6 \mathrm{~cm} \times 4 \mathrm{~cm} \times 3 \mathrm{~cm}$ and $3.5 \mathrm{~cm} \times 2 \mathrm{~cm} \times 2 \mathrm{~cm}$, respectively 


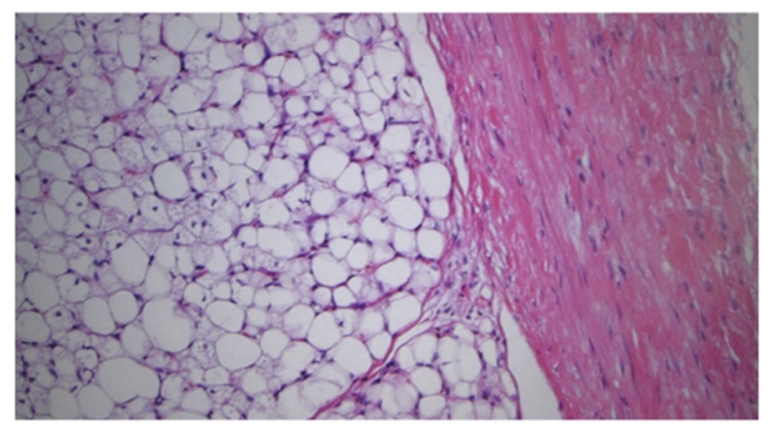

Fig. 5 Pathological analysis. Microscopically, both tumors were multilobulated tumors of adipose tissue and were surrounded by the capsule composed of loose connective tissue. The both tumors were diagnosed as lipoblastoma (hematoxylin-eosin stain, $\times 100)$ testicular lesion includes teratoma, seminoma, or nonneoplastic lesion (e.g., hydrocele or inguinal hernia) [20].

Regarding the surgical treatment, malignant lesions require the gold-standard surgical approach of radical inguinal orchidectomy [25]. On the other hand, standard treatment of the lipoblastoma is the complete resection of the tumor [17], to avoid recurrence. In fact, among the previously reported cases of intrascrotal lipoblastoma (Table 1), almost all of the cases had been performed inguinal mass excision (and orchidectomy in one case). Our case is the first case in which simple tumorectomy was performed via minimal scrotal skin incision. We consider that if the adequate preoperative suspicion of lipoblastoma could be made, we can avoid the invasive procedure (inguinal exploration or orchidectomy). In our case, accurate preoperative diagnosis of this rare tumor led to the simple tumor resection via minimal scrotal skin incision and favorable postoperative recovery without recurrence.

Table 1 Summary of cases of intrascrotal lipoblastoma in the literature

\begin{tabular}{|c|c|c|c|c|c|c|c|c|c|c|c|}
\hline Patient & Authors & Year & Age & Side & $\begin{array}{l}\text { AFP } \\
(\mathrm{ng} / \mathrm{ml})\end{array}$ & $\begin{array}{l}\beta \text { hCG } \\
(U \mathrm{Ul} / \mathrm{L})\end{array}$ & $\begin{array}{l}\text { Preoperative } \\
\text { image findings }\end{array}$ & $\begin{array}{l}\text { Preoperative } \\
\text { diagnosis }\end{array}$ & Approach & Treatment & $\begin{array}{l}\text { Size of tumor } \\
(\mathrm{cm} \times \mathrm{cm} \times \mathrm{cm})\end{array}$ \\
\hline 1 & $\begin{array}{l}\text { Arda } \\
\text { et al. }\end{array}$ & 1993 & 15 months & Left & N.A & N.A & N.A & N.A & Inguinal & Mass excision & $6.5 \times 4 \times 3$ \\
\hline 2 & $\begin{array}{l}\text { Turner } \\
\text { et al. }\end{array}$ & 1998 & 9 months & Left & 11 & 1.8 & $\begin{array}{l}\text { US: lobulated solid } \\
\text { lesion with well- } \\
\text { defined margin. }\end{array}$ & N.A & Inguinal & Mass excision & $5 \times 2.5 \times 1.5$ \\
\hline 3 & Chun & 2001 & 18 months & N.A & N.A & N.A & N.A & N.A & N.A & N.A & $2.3 \times 2 \times 1.3$ \\
\hline 4 & $\begin{array}{l}\text { Somers } \\
\text { et al. }\end{array}$ & 2004 & 7 months & Left & N.A & N.A & $\begin{array}{l}\text { US: heterogeneous mass } \\
\text { consisting of small cystic } \\
\text { areas admixed with } \\
\text { solid components. }\end{array}$ & N.A & Inguinal & Mass excision & $14 \times 14 \times 8^{a}$ \\
\hline 5 & $\begin{array}{l}\text { Dy } \\
\text { et al. }\end{array}$ & 2007 & 4 years & N.A. & N.A & N.A & N.A & N.A & Inguinal & Mass excision & $3.5 \times 2 \times 2$ \\
\hline 6 & $\begin{array}{l}\text { Del Sordo } \\
\text { et al. }\end{array}$ & 2007 & 4 years & Right & N.A & N.A & N.A & N.A & Inguinal & Mass excision & $2 \times 1.2 \times 0.8$ \\
\hline 7 & $\begin{array}{l}\text { Robb } \\
\text { et al. }\end{array}$ & 2010 & 10 months & Left & N & $N$ & $\begin{array}{l}\text { US: echogenic mass } \\
\text { with good vascularity, } \\
\text { separate to the testis. }\end{array}$ & RMS & Inguinal & $\begin{array}{l}\text { Orchidectomy } \\
\text { and Mass } \\
\text { excision }\end{array}$ & $3 \times 2.5 \times 1.5$ \\
\hline 8 & $\begin{array}{l}\text { Kamel } \\
\text { et al. }\end{array}$ & 2011 & 4 months & Right & N.A & N.A & $\begin{array}{l}\text { US and CT: large fatty } \\
\text { tumor. }\end{array}$ & Lipoblastoma & Inguinal & Mass excision & $10 \times 9 \times 7$ \\
\hline 9 & $\begin{array}{l}\text { Nakib } \\
\text { et al. }\end{array}$ & 2013 & 10 years & Right & $N$ & $N$ & $\begin{array}{l}\text { US: a hyper-echoic lesion } \\
\text { above the upper pole } \\
\text { of the testicle. }\end{array}$ & N.A & N.A & Mass excision & $5 \times 5 \times 1.5$ \\
\hline 10 & $\begin{array}{l}\text { Eyssartier } \\
\text { et al. }\end{array}$ & 2013 & 15 months & Left & 17 & 4 & $\begin{array}{l}\text { US: echogenic solid } \\
\text { lesion with well-defined } \\
\text { margin. }\end{array}$ & N.A & Inguinal & Mass excision & $2 \times 1.5 \times 1$ \\
\hline 11 & $\begin{array}{l}\text { Eyssartier } \\
\text { et al. }\end{array}$ & 2013 & 16 months & Right & 7.8 & $<1$ & US: an echogenic mass. & N.A & Inguinal & Mass excision & $1.5 \times 1.5 \times 2$ \\
\hline 12 & $\begin{array}{l}\text { Present } \\
\text { case }\end{array}$ & 2015 & 19 months & Right & 6.0 & 225 & $\begin{array}{l}\text { US: hyper-echoic } \\
\text { lobulated mass with } \\
\text { well-circumscribed } \\
\text { margin. } \\
\text { CT: less enhanced mass. } \\
\text { MRI: TI high/low, T2 high. }\end{array}$ & Lipoblastoma & Scrotal & Mass excision & $\begin{array}{l}6 \times 4 \times 3,3.5 \times \\
2 \times 2\end{array}$ \\
\hline
\end{tabular}




\section{Conclusions}

A rare intrascrotal lipoblastoma is seldom made accurate preoperative diagnosis; however, the accurate preoperative suspicion of this tumor leads to the minimal invasive tumorectomy via scrotal skin incision and favorable postoperative recovery without recurrence.

\section{Consent}

Written informed consent was obtained from the parents of the patient for publication of this case report and any accompanying images. A copy of the written consent is available for review by the Editor-in-Chief of this journal.

\section{Abbreviations}

AFP: alpha-fetoprotein; b-hcg: beta-human chorionic gonadotropin; $\mathrm{CT}$ : computed tomography; MNTI: melanotic neuroectodermal tumor of infancy; MRI: magnetic resonance imaging; RMS: rhabdomyosarcoma; US: ultrasonography.

\section{Competing interests}

The authors declare that they have no competing interests.

\section{Authors' contributions}

$\mathrm{KY}, \mathrm{HI}, \mathrm{HM}$, and MS equally worked in the diagnosis and surgery. KY contributed to the data collection, perioperative care, and creating the manuscript. HI was the operating surgeon and contributed to the review of the manuscript. All authors read and approved the final manuscript.

\section{Authors' information}

$\mathrm{KY}$ and $\mathrm{HM}$ are the assistant professors of surgery and worked as pediatric surgeons for more than 5 years. $\mathrm{HI}$ is the professor of pediatric surgery with experience of more than 20 years. MS is the chief professor of Gastointestinal/Pediatric Surgery.

Received: 4 January 2016 Accepted: 4 April 2016

Published online: 09 April 2016

\section{References}

1. Chung EB, Enzinger FM. Benign lipoblastomatosis. An analysis of 35 cases. Cancer. 1973;32:482-92.

2. Pham NS, Poirier B, Fuller SC, Dublin AB, Tollefson TT. Pediatric lipoblastoma in the head and neck: a systematic review of 48 reported cases. Int J Pediatr Otorhinolaryngol. 2010;74:723-8.

3. Salem R, Zohd M, Njim L, et al. Lipoblastoma: a rare lesion in the differential diagnosis of childhood mediastinal tumors. J Pediatr Surg. 2011;46:e21-23.

4. Yu DC, Javid PJ, Chikwava KR, et al. Mesenteric lipoblastoma presenting as a segmental volvulus. J Pediatr Surg. 2009;44:e25-28.

5. Koplin SA, Twohig MH, Lund DP, Hafez GR. Omental lipoblastoma. Pathol Res Pract. 2008;204:277-81.

6. Api O, Akil A, Uzun MG, et al. Fetal retroperitoneal lipoblastoma: ultrasonographic appearance of a rare embryonal soft tissue tumor. J Matern Fetal Neonatal Med. 2010;23:1069-71.

7. Arda IS, Senocak ME, Gogus S, Buyukpamukcu N. A case of benign intrascrotal lipoblastoma clinically mimicking testicular torsion and review of the literature. J Pediatr Surg. 1993;28:259-61.

8. Turner DT, Shah SM, Jones R. Intrascrotal lipoblastoma. Br J Urol. 1998;81:166-7.

9. Chun YS, Kim WK, Park KW, Lee SC, Jung SE. Lipoblastoma. J Pediatr Surg. 2001;36:905-7

10. Somers GR, Teshima I, Nasr A, Cook A, Khoury AE, Taylor GP. Intrascrotal lipoblastoma with a complex karyotype: a case report and review of the literature. Arch Pathol Lab Med. 2004;128:797-800.

11. Del Sordo R, Cavaliere A, Sidoni A, Colella R, Bellezza G. Intrascrotal lipoblastoma: a case report and review of the literature. J Pediatr Surg. 2007:42:E9-11.

12. Dy JS, Fuchs A, Palmer LS. Benign intrascrotal lipoblastoma in a child. Urology. 2007;70(372):e371-372.

13. Robb A, Rogers T, Nicholls G. A tale of 3 testes? A rare presentation of lipoblastoma with a novel karyotype. J Pediatr Surg. 2010;45:E29-31.
14. Kamal NM, Jouini R, Yahya S, Haiba M. Benign intrascrotal lipoblastoma in a 4-month-old infant: a case report and review of literature. J Pediatr Surg. 2011;46:E9-12.

15. Eyssartier $E$, Villemagne $T$, Maurin L, Machet MC, Lardy H. Intrascrotal lipoblastoma: a report of two cases and a review of the literature. J Pediatr Urol. 2013;9:e151-154.

16. Nakib G, Calcaterra V, Avolio L, et al. Intrascrotal lipoblastoma in a ten year old: case report and review of literature. Rare Tumors. 2013;5:e11.

17. Kok KY, Telisinghe PU. Lipoblastoma: clinical features, treatment, and outcome. World J Surg. 2010;34:1517-22.

18. Coffin CM. Lipoblastoma: an embryonal tumor of soft tissue related to organogenesis. Semin Diagn Pathol. 1994;11:98-103.

19. Stringel G, Shandling B, Mancer K, Ein SH. Lipoblastoma in infants and children. J Pediatr Surg. 1982;17:277-80.

20. Ahmed HU, Arya M, Muneer A, Mushtaq I, Sebire NJ. Testicular and paratesticular tumours in the prepubertal population. Lancet Oncol. 2010;11: 476-83.

21. Shapiro E, Strother D. Pediatric genitourinary rhabdomyosarcoma. J Urol. 1992;148:1761-8.

22. Ferrari A, Bisogno G, Casanova M, et al. Paratesticular rhabdomyosarcoma: report from the Italian and German Cooperative Group. J Clin Oncol. 2002; 20:449-55.

23. Akbar SA, Sayyed TA, Jafri SZ, Hasteh F, Neill JS. Multimodality imaging of paratesticular neoplasms and their rare mimics. Radiographics. 2003;23: 1461-76.

24. Ha TV, Kleinman PK, Fraire A, et al. MR imaging of benign fatty tumors in children: report of four cases and review of the literature. Skelet Radiol. 1994;23:361-7.

25. Agarwal PK, Palmer JS. Testicular and paratesticular neoplasms in prepubertal males. J Urol. 2006;176:875-81.

\section{Submit your manuscript to a SpringerOpen ${ }^{\mathcal{O}}$ journal and benefit from:}

- Convenient online submission

- Rigorous peer review

- Immediate publication on acceptance

- Open access: articles freely available online

- High visibility within the field

- Retaining the copyright to your article

Submit your next manuscript at springeropen.com 